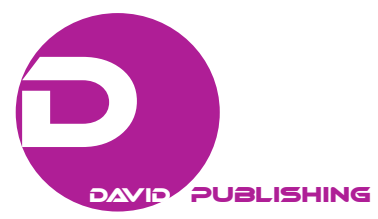

\title{
Does Market Timing Affect Capital Structure?: Evidence for Chinese Firms
}

\author{
Philip Russel \\ Philadelphia University, PA, USA \\ Ken Hung \\ Texas A\&M International University, TX, USA
}

\begin{abstract}
This paper investigates the market timing hypothesis of capital structure using a sample of 1,077 Chinese firms for the period 1992 to 2007 . We find that market timing plays a significant role in capital structure decisions. However, market timing effects are not persistent and disappear within three years. The results suggest the prominent role played by the government in timing of security issues.

Keywords: capital structure, market timing, persistence, China capital market
\end{abstract}

\section{Introduction}

There is a substantial body of theoretical and empirical research on the determinants of capital structure. One of the recent efforts to understand the capital structure decision is based on the "market timing" theory proposed by Baker and Wurgler (2002). Market timing theory suggests that managers can increase current shareholder's wealth by timing the issue of securities. Accordingly, firms are likely to issue equity when the stock prices are overvalued and repurchase equity when stock prices are perceived to be undervalued. Baker and Wurgler (2002) posit that market timing is an important determinant of corporate financial policy and it has a persistent impact on capital structure.

This paper contributes to the available evidence on the relationship between capital structure decision and market timing by examining a sample of 1,077 firms listed in China. While some work has been done, there is a need for additional research due to three main reasons. First, the evidence from current papers is not consistent. For example, Duan, Shou, and Jian (2006) reported that the effect of market timing on capital structure is felt for as long as five years while Li (2006) and Zhang and Tang (2006) observed that the long-run effect is not significant. Hu, Yan, and Deng (2008) suggested that market timing has little influence on the capital structure. Second, the choice of metrics may not be the most appropriate for analyzing market timing effects. The studies, to date, use M/B or EFWAMB as the measure of market timing. Kayhan and Titman (2007) pointed out that using $\mathrm{M} / \mathrm{B}$ or EFWAMB as the measure of market timing is not accurate. Third, the empirical results to date are based on pre-2005 data. However, the years of 2006 and 2007 were marked by high valuation in Chinese

Philip Russel, Associate Professor, Kanbar College of Design, Engineering and Commerce, School of Business Administration, Philadelphia University.

Ken Hung, Professor, Division of International Banking and Finance Studies, Texas A\&M International University.

Correspondence concerning the article should be addressed to Philip Russel, 4201 Henry Avenue, Philadelphia University, Philadelphia, PA 19144, USA. E-mail: russelp@philau.edu. 
stock market thereby, making these years an interesting and relevant time window to test for market timing,

The rest of the paper is organized as follows. The following section reviews the relevant literature. The methodology section introduces the regression model used to test market timing effects. It is followed by discussion of the data used in the study and empirical results. The final section is the conclusion part.

\section{Literature Review}

There are three important theories on determinants of capital structure: Irrelevance theory (Modigliani \& Miller, 1958), Trade-off theory (Modigliani \& Miller, 1963; DeAngelo \& Masulis, 1980), and Pecking order theory (Myers, 2001). In their original essay, Modigliani and Miller (1958) proved that under certain restrictive assumptions (no taxes, no transaction costs, and no information asymmetry), the value of firm or the cost of capital is not affected by its capital structure. Their later work in 1963 pointed out that the value of the firm is maximized when the firm is fully leveraged due to tax shield benefit of debt. The trade-off theory posits that there exists an optimal debt ratio, which is based on the trade-off between the tax benefits of debt and the bankruptcy and agency cost of debt. The pecking order theory recognizes the information asymmetry between managers and investors and differential cost of various sources of financing and asserts that firms will raise funds in the following pecking order - internal funds followed by debt and then equity.

The seminal work of Modigliani and Miller (1958) was followed by a series of theoretical and empirical capital structure research. While several factors have been identified in the literature as potential determinants of capital structure, there are no conclusive answers as to what constitutes an optimal leverage ratio, what is the relative contribution of different variables to a firm's leverage ratio, and what is the effect of capital structure on cost of capital and value of the firm. As Myers (2001) aptly notes, "Even 40 years after the Modigliani and Miller research, our understanding of these firms' financing choices is limited" (p. 82).

The market timing hypothesis for capital structure has attracted much attention in recent years following Baker and Wurgler (2002). While the short-run phenomenon of market timing is well documented in the literature (Taggart, 1977; Ikenberry, Lakonishok, \& Vermaelen, 1995), Baker and Wurgler's (2002) research was the first to draw attention to the long-term implications of market timing on capital structure decisions. They examined the propensity of managers to "time the equity markets" by using the book-to-market ratios $(\mathrm{M} / \mathrm{B})$ and the historical market-to-book ratio (external finance weighted average market-to-book ratio-EFWAMB) as the measure of market timing. Based on their study of a sample of US for the period of 1968-1999, they found that market timing is significantly related to the capital structure and the fluctuations in market valuations have large effects on capital structure that persists for at least a decade. Since then several researchers have contributed to the growing literature on the link between market timing and capital structure decision. The results have been mixed.

Mittoo and Zhang (2006) and Bie and Haan (2007) examined market timing and its effects on capital structure based on a sample of Canadian and Dutch firms respectively by using EFWAMB as the measure of market timing. Their results demonstrate that market timing does have an impact on the capital structure, but the impact does not persist for a long time. Kayhan and Titman (2007) improves the measure of market timing by splitting Baker and Wurgler's (2002) EFWAMB into two parts: Yearly timing (YT) and Long-term timing (LT). The former is used to measure the degree of stocks' mispricing, the latter is the growth opportunity reflected in the stock price. The results based on a sample of US firms for the period of 1960-2003 again support the finding that market timing influences capital structure but the impact is not persistent. Similar 
results are observed by Korajczyk and Levy (2003) who noted that managers tend to time the issue the securities based on macroeconomic conditions. Chazi and Tripathy (2007) tested the market timing hypothesis by using insider trading as a metric in addition to market-to-book used by Baker and Wurgler (2002). Their results support the market timing hypothesis. Mahajan and Tartaroglu (2008) used M/B and EFWAMB as the measure of market timing to test the market timing hypothesis of capital structure in major industrialized countries (G-7). They find that in all G-7 countries, except Japan, the effect of equity issuance and the impact of equity market timing attempts on leverage is short lived.

While the literature on market timing effect continues to expand, the results are mixed. This paper contributes to the existing literature by investigating the Chinese market and provides empirical support for the role of market timing in capital structure decisions in the short-run.

\section{Research Methodology}

Following Baker and Wurgler's (2002) research we hypothesize that the capital structure is influenced by marker timing, tangible assets, size, and profitability. However, we use the modified metric proposed by Kayhan and Titman (2007) as the measure of market timing. We modify a few other variables in the model as well based on survey of literature and also to make it more relevant for the Chinese financial data.

\section{Measure of Market Timing}

Following Baker and Wurgler (2002), EFWAMB is a measure of market timing. Kayhan and Titman (2007) suggested that the value of EFWAMB may be disaggregated into two components (yearly timing, YT, and long-term timing, LT) as follows:

$$
\begin{gathered}
E F W A M B_{t-1}=\sum_{s=0}^{t-1} \frac{e_{s}+d_{s}}{\sum_{r=0}^{t-1} e_{r}+d_{r}} \times(M / B)_{s}=\frac{\operatorname{cov}(F D, M / B)}{\overline{F D}}+\overline{(M / B)}=\frac{Y T+L T}{\overline{F D}} \\
\text { LT(Long - term timing) } \left.)_{t-1}=\sum_{s=0}^{t-1}(M / B)_{s} / t\right) *\left(\sum_{s=0}^{t-1} F D_{s} / t\right)=\overline{M / B} * \overline{F D} \\
\text { YT(Yearly Timing) }{ }_{t-1}=\left(\sum_{s=0}^{t-1} F D_{s} *(M / B)_{s}\right) / t-\overline{M / B} * \overline{F D}=\operatorname{cov}(F D, M / B)
\end{gathered}
$$

Similar to Baker and Wurgler (2002), $\overline{F D}=(\overline{e+d})$ represents the sum of average external financing over the period 0 to $t-1$. $e$ represents net equity issue; $d$ represents net debt issue. $\operatorname{Cov}(\mathrm{FD}, \mathrm{M} / \mathrm{B})$ is the covariance between external financing and market valuation. $M$ and $B$ represent market value and book value of equity respectively. If market timing hypothesis is valid, YT and LT are expected to be negatively related to leverage indicating that firms prefer to issue equity when stock prices are overvalued.

\section{Measure of Leverage-D/A, Net Financial Liabilities/Net Operational Assets}

Studies in the past have used "total liabilities/total assets" (D/A) as the measure of capital structure. However, it is not clear whether the measures of "total assets" and "total liabilities" come from standard balance sheet released by the listed firms or management balance sheet which has been adjusted. If it comes from standard balance sheet, we have "total liabilities/total assets = (operational liabilities + financial liabilities) / (operational liabilities + financial liabilities + book value of equity)". This shows that the data of "total liabilities/total assets" not only depends on the financial liabilities and equity arising from financing decision-making, but is also affected by operational actives such as accounts payable, wages payable, taxes 
payable, and notes payable. Thus, the measure of capital structure calculated above can not accurately address the issue of whether market timing affects managers capital structure decisions.

In order to avoid the influence of operational liabilities, we use management balance sheet as the basis of our calculation. Thus, "total liabilities in management balance sheet" = "net financial liabilities in standard balance sheet" = "financial liabilities-financial assets in standard balance sheet", "total assets in management balance sheet" = "net operational assets in standard balance sheet" = "operational assets-operational liabilities in standard balance sheet". We believe "D/A" measure based on the management balance sheet more accurately capture managers' decision-making.

\section{Measure of Tangible Assets-Fixed Assets/Net Operational Assets}

Tangible assets of a firm can be used as collateral. Therefore, the greater the proportion of tangible assets on the balance sheet, the more willing should lenders be to supply loans, and leverage will tend to be higher (Rajan \& Zingales, 1995; Baker \& Wurgler, 2002). Thus, the proportion of tangible assets may be one of the factors correlating with leverage.

There are different measures for tangible assets. Some use "fixed assets/total assets" (Rajan \& Zingales, 1995), and others use "(fixed assets + inventory)/total assets" (Hu et al., 2008). Again, the final results will vary depending on whether the assets are based on standard balance sheet or management adjusted balance sheet. In theory, accounts receivable, inventory can be used as collateral; However, in China, only fixed assets are acceptable as collateral by banks; Accordingly, we use "fixed assets/net operational assets" as the measure of tangible assets.

\section{Measure of Profitability-EBIT/Net Operational Assets}

The measure of profitability is inconsistent in prior literature. Some use "EBIT/total assets" (Baker \& Wurgler, 2002) and others use "revenue/total assets" (Hu et al., 2008). Trade-off theory (Modigliani \& Miller, 1963) states that a value-maximizing firm will pursue an optimal capital structure by considering the marginal costs and benefits of each additional unit of financing, and then choosing the form of financing that equates these marginal costs and benefits. Signal theory suggests that firms with better profitability are more willing to use financial leverage; therefore, profitability is positively related to the debt ratio. However, according to Pecking order theory (Myers \& Majluf, 1984), firms will prefer to finance with internal funds rather than debt. Thus all the theories of capital structure recognize that profitability correlates with capital structure. However, we must note that profitability stated in trade-off theory and signal theory refers to the company's business profitability rather than the company's profitability as a whole. Only when the profit generated from operating activities (EBIT) is greater than zero, will there be tax shield effect, and also only when EBIT/the capital invested in business is greater than the interest rate, the correlation between leverage and the company's profitability will be positive. We define profitability as referring to the company's business profitability. The most accurate measure of company's business profitability is "EBIT/net operational assets". Therefore, we select this variable as the measure of profitability.

\section{Regression Model}

We employ a regression model which is similar to Kayhan and Titman's (2007):

$$
(\mathrm{D} / \mathrm{A})_{t}=\alpha+\beta_{1}(\mathrm{YT})_{t-1}+\beta_{2}(\mathrm{LT})_{t-1}+\beta_{3}(\mathrm{~T})_{t-1}+\beta_{4}(\mathrm{EBIT} / \mathrm{A})_{t-1}+\beta_{5} \log (\mathrm{Sales})_{t-1}+\varepsilon_{t}
$$

where D/A measures capital structure in the $t$ year; $(\mathrm{YT})_{t-1},(\mathrm{LT})_{t-1},(\mathrm{~T})_{t-1}$, (EBIT/A $)_{t-1}$, and $\log (\mathrm{Sales})_{t-1}$ are measures for market timing, growth opportunities, tangible assets, profitability, and size respectively. In the 
empirical analysis, we adjust the standard balance sheet to develop management balance sheet, and then calculate the measures above.

\section{Data and Empirical Results}

We identified a total of 1,514 listed firms from Chinese stock exchange for the period January 1992 to December 2007. We excluded 27 financial firms and 164 S, ST, SST, *ST, and S*ST firms. In addition, we restricted the sample to exclude firms with missing data or firms whose capital structure is more than one or less than zero. Our filtering process yielded a final sample of 1,077 firms. We further sorted the sample by IPO time leading to a sample of 6,670 firm-year observations. Sample size of each group is shown in Table 1 . The annual data was obtained from Wind Datafeed Service (WDS).

Table 1

IPO in Every Year

\begin{tabular}{lllllllllll}
\hline Sample & IPO + 1 & IPO + 2 & IPO + 3 & IPO + 4 & IPO + 5 & IPO + 6 & IPO + 7 & IPO + 8 & IPO + 9 & IPO + 10 \\
\hline$N$ & 915 & 866 & 853 & 771 & 720 & 662 & 605 & 523 & 461 & 394 \\
\hline
\end{tabular}

Table 2 reports the regression results. We find that YT has a highly significant negative coefficient with $\mathrm{D} / \mathrm{A}$ in the third year after IPO which means that market timing is one of the determinants of leverage. Thus firms are more likely to issue equity when their market value is high, and repurchase equity or issue debt when their market value is low. However, the third year after IPO, YT does not have significant negative coefficients with D/A suggesting that there is no persistent effect of market timing. In addition, since the second year after IPO, LT has highly significant positive coefficients with D/A which means firms with more growth opportunities will issue more debt.

Table 2

Determinants of Leverage - Period: 1992-2007

\begin{tabular}{|c|c|c|c|c|c|c|c|c|c|c|}
\hline Variables & $\mathrm{IPO}+1$ & $\mathrm{IPO}+2$ & $\mathrm{IPO}+3$ & $\mathrm{IPO}+4$ & $\mathrm{IPO}+5$ & $\mathrm{IPO}+6$ & $\mathrm{IPO}+7$ & $\mathrm{IPO}+8$ & $\mathrm{IPO}+9$ & $\mathrm{IPO}+10$ \\
\hline Prof & -0.249 & $-0.313^{* * *}$ & $-0.281^{* * *}$ & $-0.283^{* * *}$ & $-0.210^{* * *}$ & $-0.158^{* * *}$ & $-0.178^{* * *}$ & $-0.199^{* * *}$ & $0.209^{* * *}$ & -0.35 \\
\hline YT & 0 & -0.037 & $-0.118^{* *}$ & 0.005 & -0.29 & 0.049 & 0.067 & $0.105^{*}$ & 0.048 & 0.019 \\
\hline $\mathrm{T}$ & 0.070 & -0.018 & $0.075^{* *}$ & $0.096^{* * *}$ & 0.36 & 0.051 & $0.089^{* *}$ & $0.102^{* *}$ & 0.064 & $0.098^{*}$ \\
\hline LT & -0.024 & $0.157^{* * *}$ & $0.126^{* * *}$ & $0.145^{* * *}$ & $0.151^{* * *}$ & $0.175^{* * *}$ & $0.226^{* * *}$ & $0.287^{* * *}$ & $0.218^{* * *}$ & $0.212^{* * *}$ \\
\hline Size & 0.181 & $0.122^{* * *}$ & $0.124^{* * *}$ & 0.045 & 0.68 & 0.037 & -0.29 & -0.16 & 0.007 & -0.052 \\
\hline $\begin{array}{l}\text { Adjusted } \\
\text { Square }\end{array}$ & $R^{R} 0.099$ & 0.131 & 0.111 & 0.106 & 0.068 & 0.047 & 0.067 & 0.089 & 0.066 & 0.038 \\
\hline$N$ & 915 & 866 & 853 & 771 & 720 & 662 & 605 & 523 & 461 & 394 \\
\hline
\end{tabular}

Notes. ${ }^{*},{ }^{* *}$, and ${ }^{* * *}$ significant at $10 \%, 5 \%$, and $1 \%$, respectively.

\section{Conclusions}

Baker and Wurgler (2002) suggested that market timing can have an impact on capital structure decisions of firms. We test this theory for a sample of Chinese firms following Baker and Wurgler's analytical framework and improved measures suggested by Kayhan and Titman (2007). We modify a few other variables to better address the research question and to make them compatible with Chinese data. Baker and Wurgler (2002) observed that the fluctuations in market valuations have significant effects on capital structure that 
persist for at least a decade in the US. However, the result in this paper shows that market timing in Chinese stock market does not have a persistent impact on capital structure. Market timing effect disappears third year after IPO. The lack of long-term effect in China may be due to the prominent role of government in monitoring the timing of security issue. Furthermore, even if managers are aware of market timing opportunities, they may not be able to execute it and create value for shareholders, due to practical impediments to re-entering the market soon after an IPO.

\section{References}

Baker, M., \& Wurgler, J. (2002). Market timing and capital structure. Journal of Finance, 57, 1-32.

Bie, T., \& Haan, L. (2007). Market timing and capital structure: Evidence for Dutch firms. De Economist, 155, $183-206$.

Chazi, A., \& Tripathy, N. (2007). Which version of equity market timing affects capital structure? Journal of Applied Finance, 17(1), 70-81.

DeAngelo, H., \& Masulis, R. W. (1980). Optimal capital structure under corporate and personal taxation. Journal of Financial Economics, 8(1), 3-29.

Duan, L., Shou, C., \& Jan, C. J. (2006). Study on the sustained effects of markets timing on capital structure. Chinese Journal of Management, 3, 85-90.

Hu, J., Yan, Y. Y., \& Deng, T. (2008). Market timing and capital structure: Evidence from China. Journal of Finance Theory and Practice, 3, 7-10.

Ikenberry, D., Lakonishok, J., \& Vermaelen, T. (1995). Market reaction to open market share repurchases. Journal of Financial Economics, 39, 181-208.

Jensen, M., \& Meckling, W. H. (1976). Theory of the firm: Managerial behavior, agency costs. Journal of Financial Economics, 3 , 305-360.

Kayhan, A., \& Titman, S. (2007). Firms' histories and their capital structure. Journal of Financial Economics, 83, 1-32.

Korajczyk, R. A., \& Levy, A. (2003). Capital structure choice: Macroeconomic conditions and financial constraints. Journal of Financial Economics, 26, 75-109.

Li, G. Z. (2006). Capital structure and market timing: Evidence from cross-section data of Chinese listed companies. Journal of Central University of Finance and Economics, 8, 22-28.

Mahajan, A., \& Tartaroglu, S. (2008). Market to book ratios, equity market timing and capital structure: International evidence. Journal of Banking and Finance, 32, 754-766.

Mittoo, U. R., \& Zhang, Z. (2006). Market timing, capital structure and cross listing: Canadian evidence. Working Paper, University of Manitoba.

Modigliani, F., \& Miller, M. H. (1958). The cost of capital, corporation finance, and the theory of investment. The American Economic Review, 48, 261-97.

Modigliani, F., \& Miller, M. H. (1963). Corporate income taxes and the cost of capital: A correction. The American Economic Review, 53, 433-443.

Myers, S. C. (2001). Determinants of corporate borrowing. Journal of Financial Economics, 5(2), 147-175.

Myers, S. C., \& Majluf, N. S. (1984). Corporate financing and investment decisions when firms have information that investors do not have. Journal of Financial Economics, 13, 187-221.

Penman, S. (2005). Financial statement analysis and securities valuation. Beijing: China Financial \& Economic Publishing House.

Rajan, R., \& Zingales, L. (1995). What do we know about capital structure some evidence from international data. Journal of Finance, 50, 1421-1460.

Ross, S. (1977). The determination of financial structure: The incentive signaling approach. Journal of Financial Economics, 8 , 23-40.

Taggart, R. A. (1977). A model of corporate financing decisions. Journal of Finance, 43(1), 1-19.

Wang, Z. W., Zhu, W. X., \& Zhao, D. Q. (2007). Market timing in seasoned equity offerings with security issue regulation and its impact on capital structure. Journal of Nankai Management Review, 10, 40-46.

Zhang, F., \& Tang, H. R. (2006). An empirical analysis of timing and its persistent effect on financing decision of listed firms. East China Economic Management, 20, 131-135. 